\title{
Muscle glycogen resynthesis during recovery from cycle exercise: no effect of additional protein ingestion
}

\author{
G. VAN HALL, S. M. SHIRREFFS, AND J . A. L. CALBET \\ Copenhagen Muscle Research Center, Rigshospitalet, DK-2200 Copenhagen, Denmark
}

\begin{abstract}
Van Hall, G., S. M. Shirreffs, and J . A. L. Calbet. Muscle glycogen resynthesis during recovery from cycle exercise: no effect of additional protein ingestion. J Appl Physiol 88: 1631-1636, 2000.-In the present study, we have investigated the effect of carbohydrate and protein hydrolysate ingestion on muscle glycogen resynthesis during $4 \mathrm{~h}$ of recovery from intense cycle exercise. Five volunteers were studied during recovery while they ingested, immediately after exercise, a 600-ml bolus and then every $15 \mathrm{~min}$ a $150-\mathrm{ml}$ bolus containing 1) $1.67 \mathrm{~g} \cdot \mathrm{kg}$ body $\mathrm{wt}^{-1} \cdot \mathrm{I}^{-1}$ of sucrose and 0.5

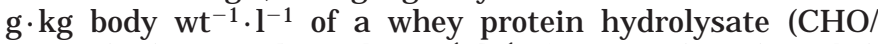
protein), 2) $1.67 \mathrm{~g} \cdot \mathrm{kg}$ body $\mathrm{wt}^{-1} \cdot \mathrm{I}^{-1}$ of sucrose (CHO), and 3) water. $\mathrm{CHO} /$ protein and $\mathrm{CHO}$ ingestion caused an increased arterial glucose concentration compared with water ingestion during $4 \mathrm{~h}$ of recovery. With $\mathrm{CHO}$ ingestion, glucose concentration was 1- $1.5 \mathrm{mmol} / \mathrm{l}$ higher during the first hour of recovery compared with $\mathrm{CHO} /$ protein ingestion. Leg glucose uptake was initially $0.7 \mathrm{mmol} / \mathrm{min}$ with water ingestion and decreased gradually with no measurable glucose uptake observed at $3 \mathrm{~h}$ of recovery. Leg glucose uptake was rather constant at $0.9 \mathrm{mmol} / \mathrm{min}$ with $\mathrm{CHO} /$ protein and $\mathrm{CHO}$ ingestion, and insulin levels were stable at 70,45 , and $5 \mathrm{mU} / \mathrm{l}$ for $\mathrm{CHO} /$ protein, $\mathrm{CHO}$, and water ingestion, respectively. Glycogen resynthesis rates were $52 \pm 7,48 \pm 5$, and $18 \pm 6$ for the first $1.5 \mathrm{~h}$ of recovery and decreased to $30 \pm 6,36 \pm 3$, and $8 \pm$ $6 \mathrm{mmol} \cdot \mathrm{kg}$ dry muscle $\mathrm{e}^{-1} \cdot \mathrm{h}^{-1}$ between 1.5 and $4 \mathrm{~h}$ for $\mathrm{CHO} /$ protein, $\mathrm{CHO}$, and water ingestion, respectively. No differences could be observed between $\mathrm{CHO} /$ protein and $\mathrm{CHO}$ ingestion ingestion. It is concluded that coingestion of carbohydrate and protein, compared with ingestion of carbohydrate alone, did not increase leg glucose uptake or glycogen resynthesis rate further when carbohydrate was ingested in sufficient amounts every 15 min to induce an optimal rate of glycogen resynthesis.
\end{abstract}

plasma glucose; glucose uptake; insulin; glucagon

MUSCLE GLYCOGEN IS AN IMPORTANT fuel for prolonged aerobic high-intensity exercise $(1,7)$. Several investigations have demonstrated that fatigue increases in parallel with decreasing muscle glycogen stores. Furthermore, the initial muscle glycogen concentration has been shown to be related to aerobic endurance performance, and a high exercise intensity cannot be maintained once the muscle glycogen stores are depleted $(4,7)$. It is important for performance and most likely for effective training to have full muscle glycogen

The costs of publication of this article were defrayed in part by the payment of page charges. The article must therefore be hereby marked "advertisement" in accordance with 18 U.S.C. Section 1734 solely to indicate this fact. stores. Because muscle glycogen resynthesis is relatively slow, and it can take $>24 \mathrm{~h}$ before complete restoration of muscle glycogen occurs, several studies have been conducted to determine ways to enhance the rate of muscle glycogen resynthesis $(4,9,20)$. Zawadski and co-workers (20) observed a faster postexercise glycogen resynthesis rate and lower venous glucose concentration if proteins were coingested with carbohydrates compared with carbohydrate ingestion alone. They suggested that the higher insulin levels with coingestion of carbohydrates and protein might have been responsible for the increased postexercise muscle glycogen resynthesis and an increased glucose clearance by the muscle. However, as mentioned by the authors, the carbohydrate supplementation regimechosen in their study resulted in a moderate glycogen resynthesis rate. Therefore, this study was conducted to investigate whether postexercise carbohydrate intake supplemented with protein can enhance muscle glycogen resynthesis rate and leg glucose uptake when the latter is close to the maximal rate observed with only carbohydrate ingestion.

\section{METHODS}

Subjects. Five healthy trained volunteers participated in this study. Their mean age, mass, height, and maximal oxygen uptake were $26 \pm 2 \mathrm{yr}, 74 \pm 2 \mathrm{~kg}, 1.78 \pm 0.03 \mathrm{~m}$, and $61 \pm 2 \mathrm{ml} \cdot \mathrm{kg}$ body mass $^{-1} \cdot \mathrm{min}^{-1}$, respectively. The subjects were informed about possible risks and discomfort involved before giving their voluntary consent to participate. The study was performed according to the Declaration of Helsinki and was approved by the Ethical Committee of CopenhagenFrederiksberg.

Protocol. E ach subject underwent three experimental trials separated by $1 \mathrm{mo}$. The three trials were identical except that during the recovery period the subjects ingested drinks that contained carbohydrate and a protein hydrolysate $(\mathrm{CHO} /$ protein), carbohydrate (CHO), or water (water). The $\mathrm{CHO} /$ protein and $\mathrm{CHO}$ trials were randomized, and the water trial was performed thereafter.

Before the experimental trials, maximal power output $\left(\mathrm{W}_{\max }\right)$ and maximal oxygen uptake were determined during a graded exercisetest on a cycle ergometer (model 818, M onark) as described previously (10). The protocol of the experimental day is shown in Fig. 1. The subjects reported to thelaboratory at 8:00 AM. After the sujects changed clothes and their body mass was measured, intense cycle ergometer exercise was started to decrease the muscle glycogen content. The glycogendepletion protocol was described previously by Kuipers et al. (10). I n short, after a warm-up period of $10 \mathrm{~min}$ at $50 \%$ of their $\mathrm{W}_{\text {max }}$, the subjects had to cycle in blocks of 2-min duration at an alternating workload of 90 and $50 \%$ of their respective $\mathrm{W}_{\text {max }}$. This was continued until they were not able to complete 


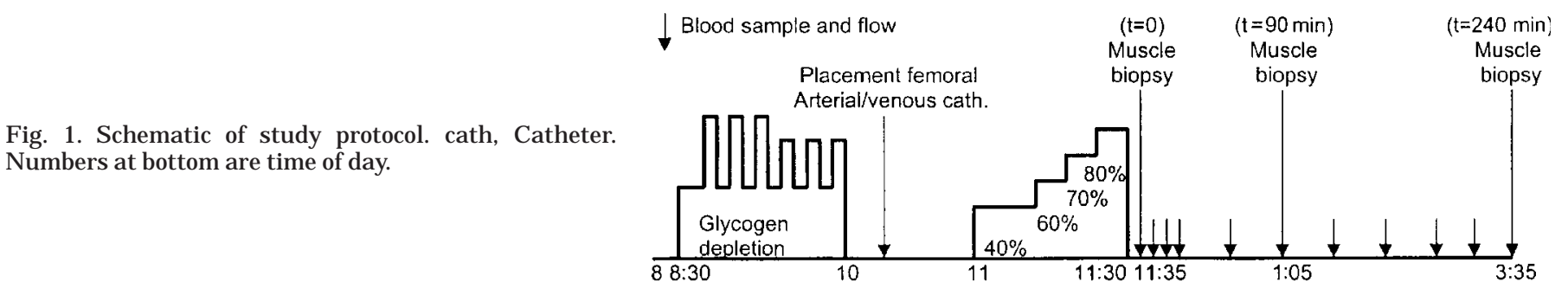

the $2 \mathrm{~min}$ at $90 \% \mathrm{~W}_{\max }$. That moment was defined as the inability to maintain a pedal rate above $60 \mathrm{rpm}$. The highintensity block was then reduced to $80 \% \mathrm{~W}_{\text {max }}$. Again the subjects had to cycle until they were unable to complete the $2 \mathrm{~min}$ at $80 \% \mathrm{~W}_{\max }$. When the $80 \% \mathrm{~W}_{\max }$ could not be completed, subjects were al lowed to stop. During the glycogendepletion exercise, the subjects were cooled with standing floor fans and water was provided ad libitum.

After cessation of the glycogen-depletion exercise, the subject immediately took a shower. Then, catheters for blood sampling and blood flow measurements were placed under local anesthesia (Lidocaine, $20 \mathrm{mg} / \mathrm{ml}$ ) in the femoral artery and vein in the inguinal region of the leg. The tip of the catheters was advanced to 5-6 cm proximal of the inguinal ligament. The arterial catheter was 20 gauge and $20 \mathrm{~cm}$ in length (Ohmeda, Swindon, UK), and the venous catheter was a radiopaque TFE catheter with side holes (Cook, Bjaeverskov, Denmark). A thermistor was inserted through the venous catheter for blood flow measurement by the constant infusion thermodilution technique (2). Placement of the catheters took $\sim 20 \mathrm{~min}$, after which the subjects remained in supine position for another 10-15 min before mounting the cycle ergometer for an incremental exercise bout. This second exercise bout started within $1 \mathrm{~h}$ of the end of the glycogen-depletion bout and was performed to abol ish the effect on metabol ism of the recovery period due to placement of the catheters so that immediate recovery could be followed. This exercise bout consisted of $14 \mathrm{~min}$ at $40 \% \mathrm{~W}_{\max }$ followed by $4 \mathrm{~min}$ at 60,70 , and $80 \% \mathrm{~W}_{\max }$. This exercise bout was to near exhaustion for the subjects, and one of the subjects was not able to complete the last $2 \mathrm{~min}$ at the highest workload in two of the three trials.

After the exercise, the subjects dismounted the ergometer and lay on the bed for the next $4 \mathrm{~h}$. I mmediately after they lay down, local anesthesia was applied to the skin (Lidocaine, 20 $\mathrm{mg} / \mathrm{ml}$ ), and an incision was made to obtain a muscle biopsy with the needle-biopsy technique (3) from the vastus lateral is muscle. Thetime between the end of the exercise bout and the muscle biopsy was on average $5 \mathrm{~min}$. The first and second biopsies were taken through the same incision. However, to avoid sampling from a damaged site, the Bergström needle was directed $3-4 \mathrm{~cm}$ in a more proximal direction compared with the initial biopsy. The third biopsy was taken from a new incision $\sim 4 \mathrm{~cm}$ distal from the first incision. The first blood sample and muscle biopsy were taken just before the first bolus of the drink was provided. The second and third biopsies were taken after 1.5 and $4 \mathrm{~h}$ of recovery. During the first hour of recovery, femoral arterial and venous blood samples were taken and blood flow was measured every 10 min; thereafter, these procedures were repeated every 30 $\min$.

The drinks during recovery were provided as a bolus. The first bolus was $600 \mathrm{ml}$, and, thereafter, the subjects received $150 \mathrm{ml}$ every $15 \mathrm{~min}$ for the next $4 \mathrm{~h}$ of recovery. The drinks contained 1) $1.67 \mathrm{~g} \cdot \mathrm{kg}$ body $\mathrm{wt}^{-1} \cdot \mathrm{I}^{-1}$ of sucrose and $0.5 \mathrm{~g} \cdot \mathrm{kg}$ body $\mathrm{wt}^{-1 \cdot 1^{-1}}$ of a whey protein hydrolysate (MD Foods, Arhus, Denmark) with an average chain length of $3.7(\mathrm{CHO} /$

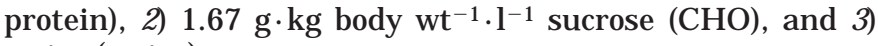
water (water).

Muscle analysis. Muscle specimens of $\sim 50-70 \mathrm{mg}$ wet weight were immediately frozen in liquid nitrogen, freezedried, and freed from adherent blood and connective tissue. Glycogen was measured in duplicate with 2-3 mg of dry muscle tissue. For the glycogen determination, glycogen was hydrolyzed with $1 \mathrm{M} \mathrm{HCl}$ for $3 \mathrm{~h}$ at $100^{\circ} \mathrm{C}$ and then neutralized with $0.12 \mathrm{M}$ Tris-2.1 $\mathrm{M} \mathrm{KOH}$ saturated with $\mathrm{KCl}$. The supernatant was analyzed for glucose (Roche UniKit, Paris, France) on an automatic analyzer (Cobas F ara, Roche, Basel, Switzerland).

Blood analysis. Femoral arterial and venous blood was collected into EDTA-containing tubes, immediately centrifuged at $4^{\circ} \mathrm{C}$ to obtain plasma, and stored at $-40^{\circ} \mathrm{C}$. Plasma glucose was analyzed on an automatic analyzer (Cobas F ara, Roche). Plasma insulin (Pharmacia, Uppsala, Sweden) and glucagon (Linco, St. Charles, MO) were determined with a radioimmunoassay kit.

Calculations. Glucose uptake across the leg was calculated as the difference in concentration between femoral arterial and venous plasma multiplied by the blood flow. Muscle glycogen resynthesis rate was calculated between 0 and $1.5 \mathrm{~h}$ $\left(t_{1}\right)$ and 1.5 and $4 \mathrm{~h}\left(t_{2}\right)$ of recovery from the following equation (in which brackets denote concentration): glycogen resynthesis rate $=$ \{glycogen $\left.]_{\left(t_{2}\right)}-[\text { glycogen }]_{\left(t_{1}\right)}\right\}\left(t_{2}-t_{1}\right)$. Net glucose uptake in millimoles for the first $1.5 \mathrm{~h}$ and between 1.5 and $4 \mathrm{~h}$ of recovery was calculated from the leg glucose uptake rates of the two consecutive time points, multiplied by the time span, and summed for the time period of 0-1.5 and 1.5-4 h. Glucose needed for glycogen resynthesis was estimated from the net increase in muscle glycogen concentration multiplied by $1.4 \mathrm{~kg}$ of dry weight muscle. If it is assumed that $6 \mathrm{~kg}$ of the $\sim 8 \mathrm{~kg}$ of leg muscle (1.4 kg dry wt) was engaged in the cycle exercise (15) and depleted to the same extent as the vastus lateral is muscle.

Statistical analysis. All data are means \pm SE from five subjects. Statistical analysis of the data was done by using the nonparametric Wilcoxon signed-rank test to determine differences between data obtained in thethree different trials for each point in time. Statistical significance was set at $\mathrm{P}<$ 0.05 .

\section{RESULTS}

Arterial glucose concentration and leg gl ucose uptake (Fig. 2). The highest arterial glucose concentration was reached 20 min after the first bolus of $\mathrm{CHO} /$ protein and $\mathrm{CHO}$ was ingested, with values of $8.7 \pm 0.3$ and $9.6 \pm$ $0.2 \mathrm{mmol} / \mathrm{l}$, respectively, after which glucose concentration decreased gradually to $\sim 6.3 \mathrm{mmol} / \mathrm{l}$ for both drinks. In contrast, with water ingestion, glucose concentration was lower for the first 20 min but returned to a stable level of $\sim 5.2 \mathrm{mmol} / \mathrm{l}$ after $1 \mathrm{~h}$ of recovery. The arterial glucose concentration was higher with $\mathrm{CHO} /$ protein and $\mathrm{CHO}$ ingestion compared with the concen- 

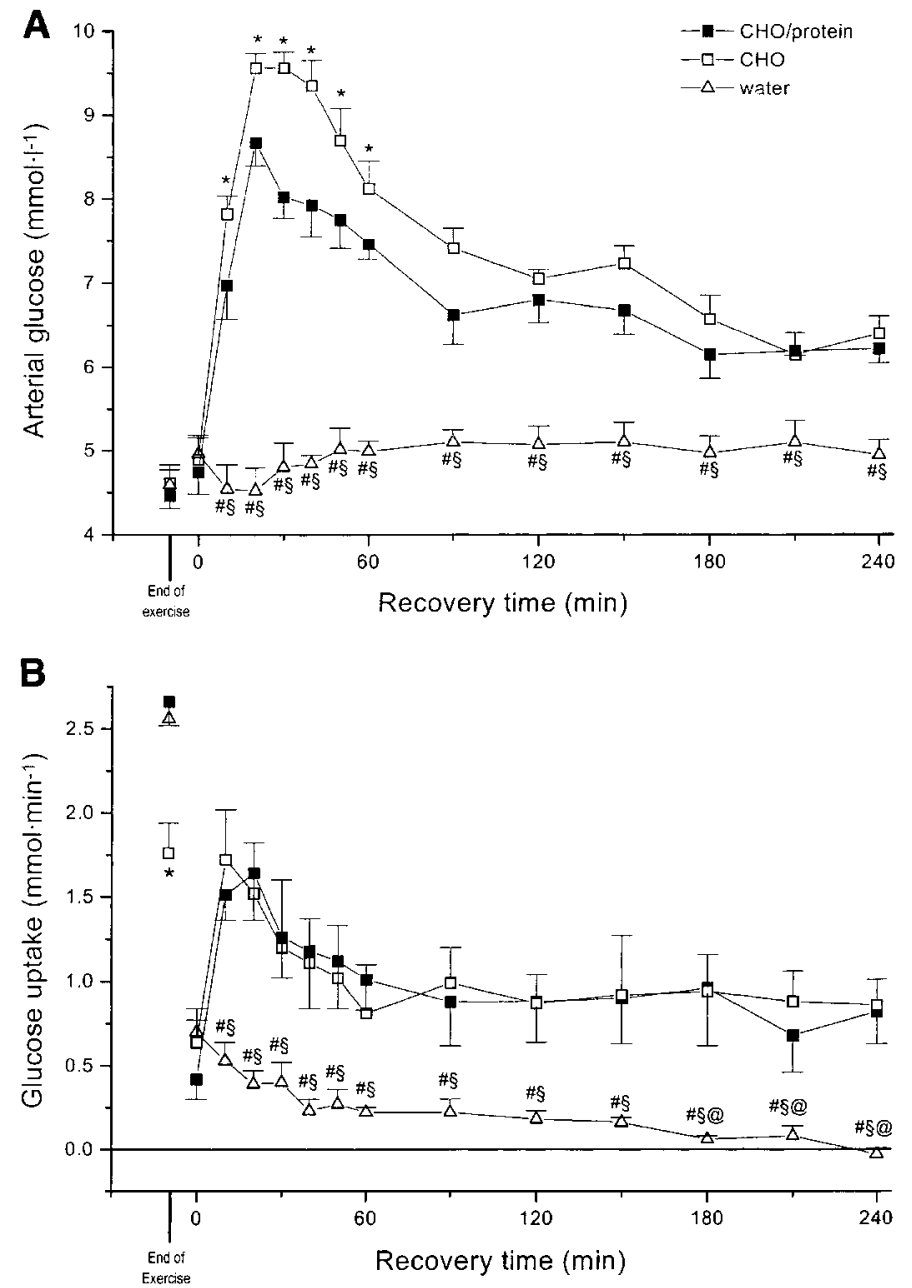

Fig. 2. Femoral arterial concentrations and leg glucose uptake rates of glucose during recovery from intense exercise. Arterial glucose concentration (A) and leg glucose uptake (B) during $4 \mathrm{~h}$ of recovery from intense exercise are shown. Values are means \pm SE of 5 subjects. $\mathrm{CHO} /$ protein, carbohydrate and protein hydrolysate ingestion; $\mathrm{CHO}$, carbohyrate ingestion; water, water ingestion. *Significant differences $\mathrm{CHO}$ vs. $\mathrm{CHO} /$ protein trial, $\mathrm{P}<0.05$. \#Significant differences water vs. $\mathrm{CHO} /$ protein trial, $\mathrm{P}<0.05$. ${ }^{\S}$ Significant differences water vs. CHO trial, P $<0.05$. @Nonsignificant exchange across the leg.

traton with water ingestion for the entire $4 \mathrm{~h}$ of recovery.

Leg glucose uptake was highest ( $1.6 \mathrm{mmol} / \mathrm{min}) 10$ and 20 min after the first bolus of the $\mathrm{CHO} /$ protein and $\mathrm{CHO}$ drinks was ingested. Leg glucose uptake then decreased, and, after $1 \mathrm{~h}$, the leg glucose uptake was at a steady state of $\sim 9 \mathrm{mmol} / \mathrm{min}$. No differences in leg glucose uptake between the $\mathrm{CHO} /$ protein and $\mathrm{CHO}$ drink could be observed at any time during the $4 \mathrm{~h}$ of recovery. With water ingestion, the leg glucose uptake was initially $0.7 \mathrm{mmol} / \mathrm{min}$ but decreased gradually, and, after $3 \mathrm{~h}$ of recovery, no measurable glu cose uptake could be observed.

Arterial insulin and glucagon concentrations (Fig. 3). Arterial insulin increased considerably during recovery as a result of $\mathrm{CHO}$ ingestion. During the entire $4 \mathrm{~h}$ of recovery, insulin concentration was higher with $\mathrm{CHO}$ / protein ingestion (70-80 $\mathrm{mU} / \mathrm{l})$ than with $\mathrm{CHO}$ inges- tion (40-50 $\mathrm{mU} / \mathrm{l}$ ), and it was only $\sim 5 \mathrm{mU} / /$ with water ingestion. Arterial glucagon decreased after ingestion of the first bolus for all three drinks. The arterial glucagon concentration was higher during recovery with $\mathrm{CHO} /$ protein $(90 \mathrm{ng} / \mathrm{l}$ ) compared with $\mathrm{CHO}$ ingestion $(50 \mathrm{ng} / \mathrm{l})$. With only water ingestion, the glucagon concentration was between that of the $\mathrm{CHO} /$ protein and $\mathrm{CHO}$ trial, but it failed to have a consistently significant difference from either drink.

Muscle glycogen content and resynthesis rate (Fig. 4). The glycogen depletion exercise and the $26 \mathrm{~min}$ of incremental exercise resulted in a muscle glycogen concentration that was the same for the three trials (CHO/protein, $69 \pm$ 10; CHO, $90 \pm 23$; water, $78 \pm 11$ $\mathrm{mmol}^{\prime}$ glycosyl units $^{-1} \cdot \mathrm{kg}$ dry muscle $\mathrm{e}^{-1}$ ).

No differences in glycogen resynthesis rate were observed between the $\mathrm{CHO} /$ protein and $\mathrm{CHO}$ trial for either the first $1.5 \mathrm{~h}$ or between 1.5 and $4 \mathrm{~h}$ of recovery. Glycogen resynthesis rate during the first $1.5 \mathrm{~h}$ of recovery was $\sim 50 \mathrm{mmol}$ glycosyl units. $\mathrm{kg}$ dry
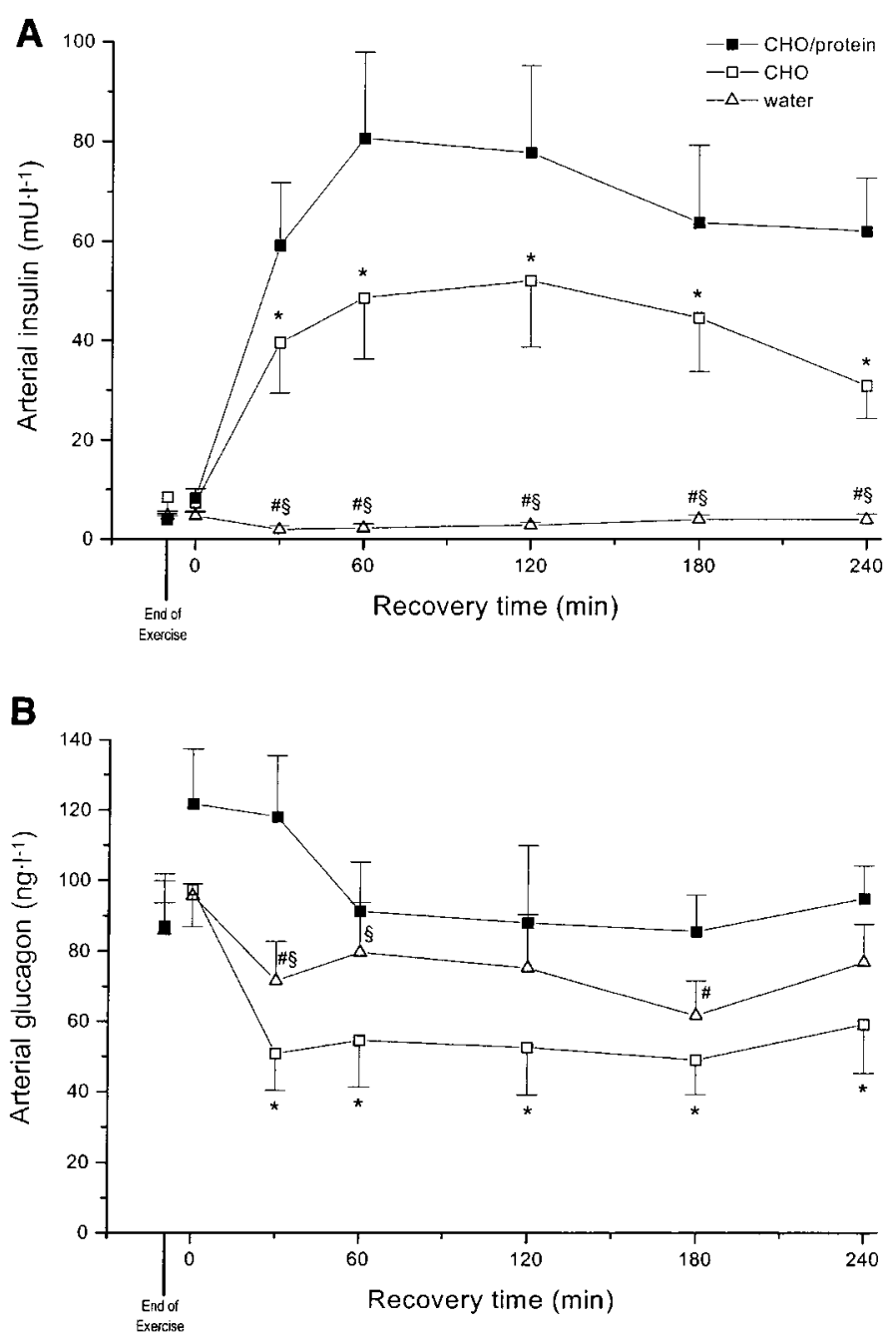

Fig. 3. Arterial insulin and glucagon concentrations. Arterial insulin (A) and arterial glucagon (B) concentrations during $4 \mathrm{~h}$ of recovery form intense exercise. Values are means \pm SE of 5 subjects. ${ }^{*}$ Significant differences $\mathrm{CHO}$ vs. $\mathrm{CHO} /$ protein trial, $\mathrm{P}<0.05$. \#Significant differences water vs. $\mathrm{CHO} /$ protein trial, $\mathrm{P}<0.05$. ${ }^{\S}$ Significant differences water vs. CHO trial, $\mathrm{P}<0.05$. 
A

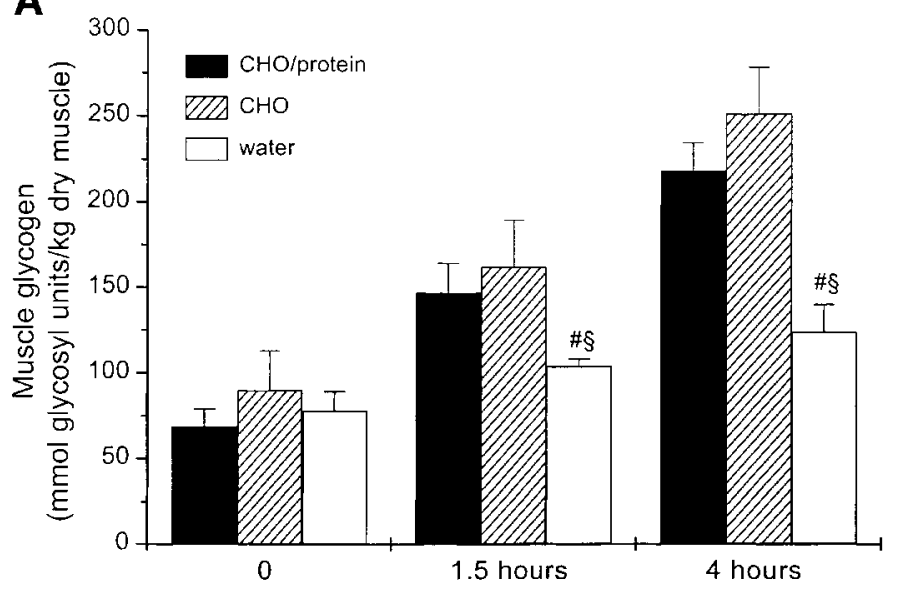

B

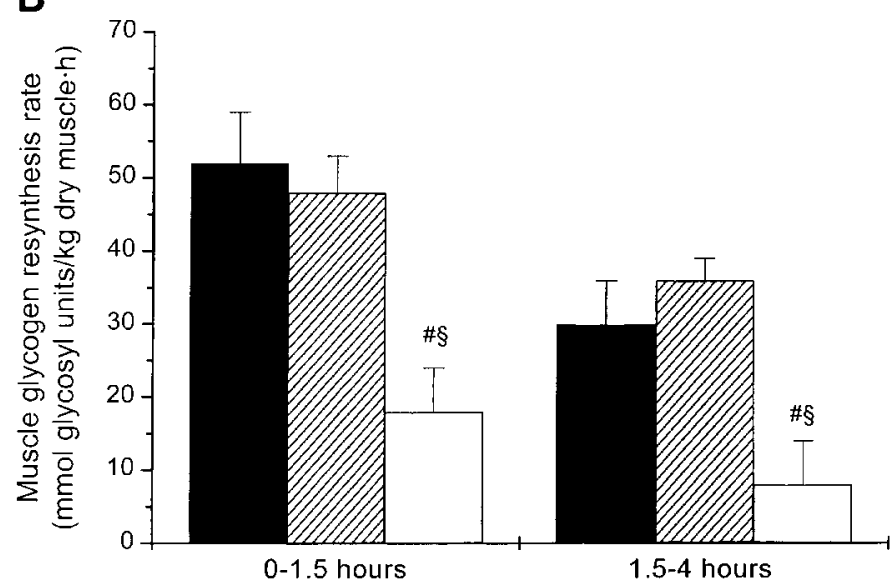

Fig. 4. Leg muscle glycogen concentration and muscle glycogen resynthesis rate during recovery from intense exercise. Muscle glycogen content (A) and muscle glycogen resynthesis rate (B) in vastus lateralis muscle during $4 \mathrm{~h}$ of recovery from intense cycle exercise. Values are means \pm SE of 5 subjects. \#Significant differences from $\mathrm{CHO} /$ protein trial, $\mathrm{P}<0.05$. ${ }^{\S}$ Significant differences from $\mathrm{CHO}$ trial, $\mathrm{P}<0.05$.

muscle $\cdot \mathrm{h}^{-1}$ and decreased to a rate of $30 \mathrm{mmol}$ glycosyl units $\cdot \mathrm{kg}$ dry muscle $\cdot \mathrm{h}^{-1}$ between 1.5 and $4 \mathrm{~h}$ of recovery. With only water ingestion, the glycogen resynthesis rate during the first $1.5 \mathrm{~h}$ was $18 \mathrm{mmol}$ glycosyl units $\cdot \mathrm{kg}$ dry muscle $\mathrm{e}^{-1} \cdot \mathrm{h}^{-1}$ and decreased to $8 \mathrm{mmol}$ glycosyl units $\cdot \mathrm{kg}$ dry muscl $\mathrm{e}^{-1} \cdot \mathrm{h}^{-1}$ thereafter.

Leg glucose uptake compared with glucose incorporated in muscl eglycogen (Fig. 5). I f we assume that $6 \mathrm{~kg}$ of muscle in the leg (of a total of $8 \mathrm{~kg}$ ) is depleted to the same extent as the vastus lateral is muscle during cycle exercise, the comparison between total leg glucose uptake and gl ucose needed for glycogen resynthesis can be made. In Fig. 5, the total leg glucose uptake during the 0-1.5 and 1.5-4 $\mathrm{h}$ of recovery is shown together with the estimated amount of glucose needed for the glycogen synthesized (Fig. 4). During the first $1.5 \mathrm{~h}$ of recovery, a nearly $100 \%$ match is found for the amount of glucose taken up by the leg and the amount of glucose needed for the observed increase in muscle glycogen content. Between 1.5 and $4 \mathrm{~h}$ of recovery it appears that more glucose is taken up by theleg than is incorporated into glycogen.

\section{DISCUSSION}

In this study we have investigated muscle glycogen resynthesis and leg glucose uptake during $4 \mathrm{~h}$ of recovery from intense cycl e exercise leading to glycogen depletion. The major findings were that neither a high rate of muscle glycogen resynthesis with $\mathrm{CHO}$ intake nor leg glucose uptake was affected by additional protein ingestion.

Glucose uptake by the skeletal muscle is facilitated mainly via the GLUT-4 transporter. Stimulation of glucose transport by insulin is mediated by translocation of GLUT-4 from the intracellular sites to the plasma membrane (11). Skeletal muscle translocation of GLUT-4 to the plasma membrane appears also to be facilitated by muscle contraction independent of insulin. It is suggested that, during the initial phase of recovery from exercise, GLUT-4 still resides in the plasma membrane because of contraction-mediated GLUT-4 translocation during the exercise bout, and thus glucose can be transported independently of insulin $(6,8)$. After the relatively short period of insulin independent muscle glucose uptake, glucose uptake and GLUT-4 translocation to the plasma membrane become insulin dependent. However, during recovery from exercise, there is a marked increase in the sensitivity to insulin of muscle glucose uptake and glycogen synthesis $(14,16,18)$. Recently, evidence has been presented suggesting that the rate of muscle glucose uptake may control the rate of glycogen resynthesis after exercise. This proposed mechanism seems to fit nicely with our data from when the subjects ingested water. Glucose uptake was highest during the initial recovery period, and leg glucose uptake decreased with the longer time of recovery. GLUT-4 transporters that remained in the plasma membrane from the exercise bout may have caused the higher glucose uptake at the initial stage. As recovery proceeds, the muscle becomes more and more dependent on insulin to maintain

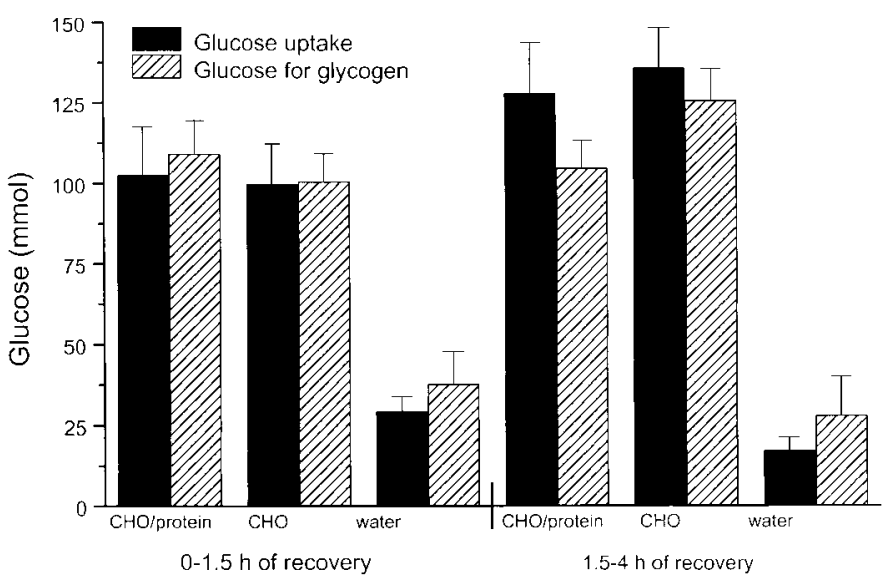

Fig. 5. Balance of leg glucose uptake and glucose needed for muscle glycogen resynthesis. Net glucose uptake for the first $1.5 \mathrm{~h}$ and between 1.5 and $4 \mathrm{~h}$ of recovery is cal culated from leg glucose uptake multiplied by time span. Glucose needed for glycogen resynthesis is estimated from net increase in glycogen concentration of vastus lateralis muscle multiplied by $1.4 \mathrm{~kg}$ of dry weight muscle. We assume that $6 \mathrm{~kg}$ of muscle (1.4 kg dry weight) in the leg is equally depleted as vastus lateralis muscle. 
GLUT-4 transporters in the plasma membrane and/or to translocate GLUT-4 to the plasma membrane. Because the insulin level in the water trial was low, the number of GLUT-4 transporters in the plasma membrane declined and, therefore, glucose uptake ceased. During the first hour of recovery, leg glucose uptake was the same for $\mathrm{CHO} /$ protein and $\mathrm{CHO}$ ingestion despitea substantially lower arterial glucose concentration with $\mathrm{CHO} /$ protein ingestion. This indicates that during the first $0.5 \mathrm{~h}$ of recovery, arterial glucose concentrations, which are considerably above basal concentrations, do not affect skeletal muscle glucose uptake. With $\mathrm{CHO} /$ protein and $\mathrm{CHO}$ ingestion, leg glucose uptake was higher during theinitial 20-30 min of recovery. This might have been caused by a greater amount of plasma membrane-bound GLUT-4 as a re sult of the previous contraction. However, glucose uptake then decreased to a constant level despite a high insulin concentration. Furthermore, the higher insulin levels with $\mathrm{CHO}$ /protein compared with $\mathrm{CHO}$ ingestion did not increase leg glucose uptake in the $\mathrm{CHO} /$ protein trial and potentially did not affect insulin-mediated GLUT-4 translocation to the plasma membrane. Because for several hours after exercise the muscle may be more sensitive to insulin $(5,14,16)$, a relative low insulin concentration may already have elicited the maximal glucose uptake and GLUT-4 translocation to the plasma membrane. Also, with $\mathrm{CHO} /$ protein and $\mathrm{CHO}$ ingestion, arterial glucose concentration did not have an effect on leg glucose uptake because glucose concentration declined with recovery time, but leg glucose uptake remained constant after $1 \mathrm{~h}$ of recovery. Muscle glycogen was measured after 1.5 and $4 \mathrm{~h}$ of recovery, and, therefore, we cannot say whether the glycogen resynthesis rate is declining over that time period.

During the first hour of recovery, arterial glucose concentration was significantly lower with $\mathrm{CHO}$ / protein ingestion compared with $\mathrm{CHO}$ alone. This lower glucose concentration might have been caused by a reduced gl ucose appearance from the gastrointestinal tract or a larger clearance by tissues other than theleg. Gastric emptying rate is suggested to depend on energy density of the ingested solution $(17,19)$, and because the energy density of the $\mathrm{CHO} /$ protein drink was higher than that of the $\mathrm{CHO}$ drink, gastric emptying may have been slowed down, thus slowing glucose appearance. This study clearly shows that changes in arterial or venous glucose concentrations do not give an indication of muscle glucose uptake because glucose uptake was not different with $\mathrm{CHO} /$ protein intake despite lower glucose concentrations.

Skeletal muscle glycogen resynthesis after exercise has been shown to be biphasic $(12,14)$ : there is the initial insulin-independent phase of 30-60 min with a high glycogen resynthesis rate followed by an insulindependent phase with a slower glycogen resynthesis rate. When Price and colleagues (14) studied glycogen resynthesis in insulin-resistant subjects and controls they did not observe a difference in glycogen resynthesis rate during the insulin-independent phase. How- ever, during the insulin-dependent phase, glycogen resynthesis rate was lower in the insulin-resistant subjects (13). These findings clearly indicate that from $1 \mathrm{~h}$ of recovery onward insulin might play an important role in the regulation of muscle glycogen resynthesis. Zawadzki and colleagues (20) reported a higher glycogen resynthesis rate during $4 \mathrm{~h}$ of recovery from exercise when carbohydrates were coingested with protein compared with when carbohydrates were ingested al one. They suggested that this was likely dueto the higher insulin level with protein coingestion, potentially via stimulation of glycogen synthase and/or glucose uptake by the muscle. Despite a substantial insulin difference between the $\mathrm{CHO} /$ protein and $\mathrm{CHO}$ trials, we were not able to find a higher glycogen resynthesis rate. There are several possible reasons to explain the apparent difference. First, the glycogen resynthesis rate of $\sim 41 \mu \mathrm{mol} \cdot \mathrm{kg}$ dry muscle $\mathrm{e}^{-1} \cdot \mathrm{h}^{-1}$, as observed by Zawadski and colleagues with $\mathrm{CHO} /$ protein intake, is nearly identical to the glycogen resynthesis rate in this study, both for $\mathrm{CHO} /$ protein and $\mathrm{CHO}$ ingestion if the average glycogen resynthesis rate from 0 to $4 \mathrm{~h}$ of recovery is considered $\left(39.8 \mu \mathrm{mol} \cdot \mathrm{kg}\right.$ dry muscle $\left.{ }^{-1} \cdot \mathrm{h}^{-1}\right)$. This glycogen resynthesis rate may be the maximal achievable after prolonged dynamic exercise with sufficient and regular carbohydrate loading despite higher insulin levels. Second, the higher insulin concentration in the $\mathrm{CHO}$ /protein trial might not have been effective. Therefore, a relative low insulin level might have elicited the maximal positive achievable effect on glycogen resynthesis during recovery from intense exercise. Third, although not directly linked to insulin levels, is the much lower muscle glycogen content immediately after exercise in our study, with an average of 79 vs. $\sim 183 \mathrm{mmol} / \mathrm{kg}$ dry muscle (213 $\mu \mathrm{mol} / \mathrm{g}$ protein), that could have had an effect on the time course of the fast and slow glycogen recovery phase. It is suggested that glycogen resynthesis rate is affected by initial concentration when muscle glycogen content is $<120 \mathrm{mmol} / \mathrm{kg}$ dry muscle (14).

If we assume that $6 \mathrm{~kg}$ of muscle in the leg (of a total of $\sim 8 \mathrm{~kg}$ ) is depleted to the same extent as the vastus lateralis muscle during cycle exercise, the comparison between total leg glucose uptake and gl ucose needed for glycogen resynthesis can be made. In Fig. 5 thetotal leg glucose uptake during the 0 - to 1.5-h and the 1.5- to 4-h recovery period is shown together with the estimated amount of glucose needed for glycogen resynthesis. During the first $1.5 \mathrm{~h}$ of recovery, a nearly $100 \%$ match is found for the amount of glucose taken up by the leg and the amount of glucose needed for the observed increase in muscle glycogen content. Between 1.5 and $4 \mathrm{~h}$ of recovery, it appears that more glucose is taken up by the leg than incorporated into glycogen. These results indicate that during the initial phase of recovery, glucose is mainly used for glycogen resynthesis and potentially less for oxidation. F urthermore, during the early stages of recovery, glucose uptake might be the rate-limiting factor for glycogen resynthesis (see discussion above). On the other hand, between 1.5 and $4 \mathrm{~h}$ of recovery glucose uptake appears not to be rate limiting 
for glycogen resynthesis because more glucose is taken up than is stored in muscle glycogen. With water ingestion, glucose uptake is lower than the amount of glucose needed for glycogen resynthesis. This may have been due to the fact that the differences in both glucose arterial venous differences and muscle glycogen content are small and will increase variably. Another possibility is that $<6 \mathrm{~kg}$ of muscle in the leg is depleted to the same extent as in the quadriceps and that we overestimate glucose needed for glycogen resynthesis.

In conclusion, coingestion of carbohydrate and protein compared with ingestion of carbohydrate al one did not increase leg glucose uptake or the glycogen resynthesis rate after intense cycle exercise. It seems that protein ingestion per se or via stimulation of insulin secretion cannot increase muscle glycogen resynthesis rate in humans when an optimal carbohydrate supplementation regime is followed during recovery from exercise.

This study was supported by grants from MD Foods, the Danish Sport Research Council, Team Denmark Research Foundation, and the Danish National Research Foundation. G. van Hall was supported by a fellowship from the Danish Research Academy.

Address for reprint requests and other correspondence: $G$. van Hall, Copenhagen Muscle Research Center, Rigshospitalet Sect. 7652, 20 Tagensvej, DK-2200 Copenhagen N, Denmark (E-mail: RH01769@RH.DK).

Received 29 December 1998; accepted in final form 9 December 1999.

\section{REFERENCES}

1. Ahlborg B, Bergström J, Ekelund LG, and Hultman E. Muscle glycogen and muscle electrolytes during prol onged physical exercise. Acta Physiol Scand 70: 129-142, 1967.

2. Andersen $\mathbf{P}$ and Saltin B. Maximal perfusion of skeletal musclein man. J Physiol (Lond) 366: 233-249, 1985.

3. Bergström J . Muscle electrolytes in man. Determination by neutron activation analysis on needle biopsy specimens. A study on normal subjects, kidney patients, and patiens with chronic diarrhea. Scand J Clin Lab Invest Suppl 68: 7- 110, 1962.

4. Bergström J , Hermansen L, Hultman E, and Saltin B. Diet, muscle glycogen and physical performance. Acta Physiol Scand 71: 140-150, 1967.

5. Cartree GD, Young DA, Sleeper MD, Zierath J , WallenbergHenriksson H, and Holloszy J O. Prolonged increase in insulinstimulated glucose transport in muscle after exercise. Am J Physiol Endocrinol Metab 256: E494-E499, 1989.

6. Hansen PA, Nolte LA, Chen MM, and Holloszy J O. Increased GLUT-4 translocation mediates enhanced insulin sensi- tivity of muscle transport after exercise. J Appl Physiol 85: 1218-1222, 1998.

7. Hermansen L, Hultman E, and Saltin B. Muscle glycogen during prolonged severe exercise. Acta Physiol Scand 71: 129139, 1967.

8. Ivy J L and Kuo C-H. Regulation of Glut 4 protein and glycogen synthase during muscle glycogen synthesis after exercise. Acta Physiol Scand 162: 295-304, 1998.

9. Ivy J L, Lee MC, Brozinick JT, and Reed MJ. Muscle glycogen storage after different amounts of carbohydrate ingestion. J Appl Physiol 65: 2018-2033, 1988.

10. Kuipers H, Keizer HA, Brouns F, and Saris WHM. Carbohydrate feeding and glycogen synthesis during exercise in man. Pflügers Arch 410: 652-656, 1987.

11. Lund S, Holman GD, Schmitz O, and Pedersen O. Glut 4 content in the plasma membrane of rat skel etal muscle: comparative studies of the subcellular fraction method and the exofacial photolabelling technique using ATB-BMPA. FEBS Lett 330: 312-318, 1993.

12. Mæhlum S, Høstmark AT, and Hermansen L. Synthesis of muscle glycogen during recovery after prol onged severe exercise in diabetic subjects. Effect of insulin deprivation. Scand J Clin Invest 38: 35- 39, 1978.

13. Price TB, Perseghin G, Duleba A, Chen W, Chase J , Rothman DL, Shulman RG, and Shulman GI. NMR studies of muscle glycogen synthesis in insulin-resistant offspring of parents with non-insulin-dependent diabetes mellitus immediately after glycogen-depleting exercise. Proc Natl Acad Sci USA 93: 5329-5334, 1996.

14. Price TB, Rothman DL, Taylor R, Avison MJ , Shulman GI, and Shulman RG. Human muscle glycogen resynthesis after exercise: insulin-dependent and -independent phases. J Appl Physiol 76: 104-111, 1994.

15. Richardson RS, Frank LR, and Haseler LJ . Dynamic knee extensor and cycle exercise: functional MRI of muscular activity. Int J Sports Med 19: 182-187, 1998.

16. Richter EA, Garetto LP, Goodman MN, and Ruderman NB. Enhanced muscle glucose metabolism after exercise: modulation by local factors. Am J Physiol Endocrinol Metab 246: E476E 482, 1984.

17. Vist GE and Maughan RJ. The effect of osmolality and carbohydrate coingestion on the rate of gastric emptying of liquids in man. J Physiol (Lond) 486: 523-531, 1995.

18. Wallberg-Henriksson. Glucose transport into skeletal muscle. Influence of contractile activity, insulin, catecholamines and diabetis mellitus. Acta Physiol Scand 131, Suppl 564: 29-47, 1987.

19. Wisen O, Hellstrom PM, and J ohansson C. Meal energy density as a determinant of postprandial gastrointestinal adaptation in man. Scand J Gastroenterol 28: 737-743, 1993.

20. Zawadzki KM, Yaspelkis B B III, and Ivy J L. Carbohydrateprotein complex increases the rate of muscle glycogen storage after exercise.J Appl Physiol 72: 1854-1859, 1992. 